T. Kagadiy, Dr. Sc. (Phys.-Math.), Assoc. Prof., orcid.org/0000-0001-6116-4971, A. Shporta, orcid.org/0000-0002-1260-7358
Dnipro University of Technology, Dnipro, Ukraine,e-mail: kagadiy@i.ua; shportaanna@ukr.net

\title{
MATHEMATICAL MODELING IN THE CALCULATION OF REINFORCING ELEMENTS
}

Purpose. Determination of stress distribution laws for the hard stamp and an elastic plate interaction with cylindrical anisotropy. Simulation of contact interaction tasks in order to determine the processes of wear, strength, destruction and structures durability. Development of analytical methods for calculating contact interactions of structures taking into account various material properties.

Methodology. The mathematical model spatial problem of a hard stamp and a circular sector with cylindrical anisotropy interaction has been compiled. To study the model, an asymptotic method has been proposed, which allows dividing the stress-strain state of an infinite circular sector into two components and reducing the solution of the elasticity theory problem to the sequential solution of potential theory problems.

Findings. A concrete contact problem was investigated, for which the asymptotic method was used. The solution takes into account the friction that occurs in the interaction process between the rigid stamp and the elastic plate. The considered task is new and rather difficult. It causes significant difficulties when considered. Therefore, the obtained analytical solution is a useful result for further analysis or numerical calculations. The pressure values under the stamp were found, the influence of friction was taken into account.

Originality. The previously proposed method is generalized to the case of material cylindrical anisotropy. An analytical solution has been obtained for a new complex spatial contact problem.

Practical value. The asymptotic method proposed in the paper allows us to move from mechanics solving complex mixed problems to solving sequential boundary problems of potential theory - the most developed section of mathematical physics. The solutions obtained by the proposed method make it possible to analyze the stress-strain state that occurs when a hard stamp is pressed into the free face of an elastic orthotropic infinite circular sector with cylindrical anisotropy, the edges of which are fixed. The following problem is considered: in the free edge of an infinite circular sector, which is elastic, orthotropic, and also its material possesses the properties of cylindrical anisotropy, a rigid stamp is pressed. The edges of the circular sector are fixed. Application of the obtained results is possible at the calculation and design of various types of fastenings. The results can be used in calculating and designing various types of mounts.

Keywords: stamp, interaction, anisotropy, asymptotic method, spatial problems, friction, sector

Introduction. Usually, the process of transferring pressures and efforts from one part to another occurs when they are in mutual contact. Therefore, the question of modeling contact interactions is of particular importance for engineering and construction. Some problems of contact interaction were raised by L. A. Galin and the solutions proposed in his works formed the basis for the development of new directions for the development of this issue. An effective method that makes it possible to correctly calculate the stress-strain state of the elements of contact interaction was developed and described in the works by A. V. Pavlenko, L. I. Manevich.

The paper considers the problem of contact, and particularly, of the indentation, of a hard stamp into the free face of an infinite orthotropic elastic circular sector with cylindrical anisotropy. The edges of the sector are fixed. When finding a solution, the friction arising from the interaction of the stamp and the plate was taken into account. To find a solution to the problem, we use the asymptotic method [1].

Literature review. Model problems of contact interactions describe the processes of destruction and durability [2], strength, wear of building structures. The need to address these issues, manifested in practice, has led to the importance of developing methods for calculating contact interactions, as well as the study of some specific contact problems.

In [3], the problem of deformation, namely the development of plastic bands in the vicinity of a symmetric notch, is solved with the help of conformal mappings.

In [4], the problem of the boundary equilibrium of an orthotropic elastoplastic cylindrical shell with an internal longitudinal crack of arbitrary configuration was reduced to the joint solution of a system of singular integral equations, dis-

CC Kagadiy T., Shporta A., 2019 placement unambiguity conditions, plasticity conditions, and stress-bounded conditions.

When solving various problems related to the theory of elasticity, methods of a small parameter (physical or geometric) are widely used [5].

In the article [6], the author proposed an asymptotic integration method for a linear system of differential equations with a small parameter with partial derivatives and a point of return.

This topic is very important and has been considered by various authors $[7,8]$, but due to the complexity of the formulation, the tasks are still relevant.

In $[9,10]$ load transfer problems are solved by numericalanalytical methods.

Unsolved aspects of the problem. Contact problems directly relate to the engineering and construction tasks, as they determine processes of the wear, strength, destruction and durability of building structures. Accounting for real material properties, such as curvilinear anisotropy, leads to significant mathematical difficulties. Therefore, the need for analytical solutions is very significant.

Analytical solutions allow determining correctness of the results obtained by other methods, investigating the special points.

Formulation of the problem. We are given the elastic plate $R_{0} \leq r \leq \infty,-\gamma \leq \theta \leq \gamma$ fixed to the edges $\theta= \pm \gamma$. A hard stamp acts on the face $r=R_{0}$, which occurs at section $-\lambda \leq \theta \leq \lambda$ with a base that coincides with the face $r=R_{0}$, and loaded with normal $P_{0}$ and tangential $Q_{0}$ forces. The friction between the stamp and the plate is taken into account, which obeys Coulomb's law (the state of the limiting balance of a stamp is considered). The displacements and deformations are equal to zero at infinity $(r \rightarrow \infty)$. The plate, $\delta$ operating under conditions of a generalized plane stress state is thick. 
Its material is orthotropic, the main directions of anisotropy coincide with the polar coordinates $r, \theta$.

It is required to determine the laws of stress distribution under the stamp and in the plate.

Solution method. Let us introduce dimensionless coordinates $\xi, \eta$ instead of polar coordinates $r, \theta$ by the relations $r=$ $=R_{0} e^{\xi}, \theta=\eta$, then the considered problem can be reduced to integrating the equilibrium equations of the plate in displacements

$$
\begin{aligned}
& B_{1} u_{\xi \xi}+G u_{\eta \eta}-B_{2}\left(v_{\eta}+u\right)+G m v_{\xi \eta}-G v_{\eta}=0 ; \\
& G v_{\xi \xi}+B_{2} v_{\eta \eta}+B_{2} u_{\eta}+G m u_{\xi \eta}-G\left(u_{\eta}-v\right)=0,
\end{aligned}
$$

under the following boundary conditions

$$
\begin{gathered}
\sigma_{1}=B_{1}\left(R_{0} e^{\xi}\right)^{-1}\left(u_{\xi}+\vartheta_{2}\left(v_{\eta}+u\right)\right)=0 ; \\
\tau=G\left(R_{0} e^{\xi}\right)^{-1}\left(u_{\eta}+v_{\xi}-v\right)=0 ; \\
u=v=0 ; \quad(\eta= \pm \gamma) ; \quad u=c_{0} ; \\
\tau=\rho \sigma_{1} ; \quad(\xi=0,|\eta|<\lambda),
\end{gathered}
$$

the displacements and stresses are zero at infinity. In addition, the equilibrium conditions of the stamp must be satisfied

$$
\int_{-\lambda}^{\lambda} \sigma_{1}(0, \eta) d \eta+P_{0}=0 ; \quad \int_{-\lambda}^{\lambda} \tau(0, \eta) d \eta+Q_{0}=0 .
$$

Since the state considered is the state of limiting equilibrium $\left(\tau=\rho \sigma_{1}\right)$, the second condition reduces to the first one. Here, $u=u_{r} ; v=u_{\theta}$ are the components of the displacement vector of the plate; $B_{1}=E_{1} \delta /\left(1-\vartheta_{1} \vartheta_{2}\right), B_{2}=E_{2} \delta /\left(1-\vartheta_{1} \vartheta_{2}\right)$; $G=G_{*} \delta$ is stiffness of the plate on tension - compression; $\sigma_{1}$ is normal stress in the direction of the coordinate $\xi ; \tau$ is shearing stress; $E_{1}, E_{2}$ are modules of elasticity along the main directions; $G_{*}$ is shear modulus; $m=1+\vartheta_{2} B_{1} / G=1+\vartheta_{1} B_{2} / G ; \vartheta_{1}, \vartheta_{2}$ is Poisson's coefficients of plate material $\vartheta_{1} B_{2}=\vartheta_{2} B_{1} ; E F$ is stiffness of the stringer on tension - compression; $\rho$ is the coefficient of friction $(\rho<1)$; the indices $\xi$, $\eta$ denote differentiation with respect to the corresponding coordinates. Mathematical difficulties do not allow us to obtain an exact analytical solution to the problem posed. To research it, we apply the asymptotic method developed in [2, 3]. This method allows us to dissect the stress-strain state of the plate into two components, and each of them is found by successive solution of boundary value problems of the potential theory.

The results. Solution for the first type stressed state. The definition of the first type stress state (slowly varying in the direction of the coordinate $\xi$ ) in the first approximation reduces to integrating equation

$$
B_{1} u_{\xi \xi}^{1.0}+G u_{\eta \eta}^{1.0}=0
$$

with the following boundary conditions

$$
\begin{gathered}
u_{\xi}^{1.0}=0(\xi=0, \lambda<|\eta|<\gamma) ; \\
u^{1.0}=\operatorname{const}(\xi=0,|\eta|<\lambda) .
\end{gathered}
$$

Zero conditions are satisfied by derivatives of the required function at infinity. Since $\eta= \pm \gamma$, the component of the displacement vector $u$ is zero, then $u_{\xi}^{1.0}$ for $\eta= \pm \gamma$, will also be zero. The displacement $v^{1.0}$ corresponding to a given stressstrain state is found from the relation (2)

$$
v_{\eta}^{1.0}+u^{1.0}=0
$$

We introduce new independent variables $\xi_{1}=\left(G / B_{1}\right)^{1 / 2} \xi$; $y_{1}=\eta$, then the boundary value problem $(1,2)$ takes the form

$$
\begin{gathered}
u_{x_{1} x_{1}}^{1.0}+u_{y_{1} y_{1}}^{1.0}=0 ; \\
u_{x_{1}}^{1.0}=0\left(x_{1}=0, \lambda<\left|y_{1}\right|<\gamma\right) ;
\end{gathered}
$$

$$
\begin{gathered}
u^{1.0}=\operatorname{const}\left(x_{1}=0,\left|y_{1}\right|<\lambda\right) ; \\
u_{y_{1}}^{1.0}=0\left(y_{1}= \pm \gamma\right),
\end{gathered}
$$

derivatives become equal to zero at infinity.

Thus, it is required to find an analytic function $u^{1.0}$ in the half-strip $0<x_{1} \leq \infty ;\left|y_{1}\right| \leq \gamma$ by specified boundary conditions (5).

We will solve this problem by reflecting the half-strip from the plane $z_{1}\left(z_{1}=y_{1}+i x_{1}\right)$ onto the upper half-plane of images $z_{1}\left(z_{1}=y_{1}+i x_{1}\right)$

This reflection can be performed using the SchwarzChristoffel transform.

If we require the origin of coordinates to keep its position, and points $z_{1}= \pm \gamma$ to be transformed into points $\zeta_{1}= \pm 1$, then the reflection function will be written in the form

$$
\zeta_{1}=\sin \frac{\pi z_{1}}{2 \gamma}
$$

Its real and imaginary components are written as follows

$$
\eta_{1}=\sin \frac{\pi y_{1}}{2 \gamma} \operatorname{ch} \frac{\pi x_{1}}{2 \gamma} ; \quad \xi_{1}=\cos \frac{\pi y_{1}}{2 \gamma} \operatorname{sh} \frac{\pi x_{1}}{2 \gamma},
$$

and points $z_{1}= \pm \lambda$ image into points $\zeta_{1}= \pm l_{1} ; l_{1}=\sin (\pi \lambda / 2 \gamma)$.

Let $\varphi^{0}=u^{1.0}+i Q^{1.0}\left(Q^{1.0}\right.$ be a harmonic function conjugate to $\left.u^{1.0}\right)$. Then $\varphi_{1}^{0}=\varphi_{y_{1}}^{0}=u_{y_{1}}^{1.0}+i Q_{y_{1}}^{1.0}=u_{y_{1}}^{1.0}-i u_{x_{1}}^{1.0}$. The function $\varphi_{1}^{0}\left(x_{1}, y_{1}\right)$ can be defined in the half-plane $\zeta_{1}$.

It follows from conditions (5) and relations (7) that on the real axis of the half-plane at the interval $\left|\eta_{1}\right|<l_{1}$ the real component of the function $\varphi_{1}^{0}$ is known, and the imaginary component is known on the remaining part of the axis $\eta_{1}$.

The problem of determining an analytic function in the half-plane, is solved using the Keldysh-Sedov formula when on some intervals of the boundary the real component is known, and on others the imaginary component of the unknown function. Since from obtained conditions (5) it follows that on the boundary of the half-plane $\zeta_{1}$ the real component of the function $\varphi_{1}^{0}$ at the interval $\left|\eta_{1}\right|<l_{1}$ is equal to zero, and on the rest of the boundary the imaginary component is zero, then the solution for the function $\varphi_{1}^{0}$ in the whole half-plane has the form

$$
\varphi_{1}^{0}\left(\zeta_{1}\right)=\frac{A}{\sqrt{\zeta_{1}^{2}-l_{1}^{2}}}
$$

where $A-$ is a real constant; the branch of the root that is positive for positive values of the argument is chosen.

The real and imaginary components $\varphi_{1}^{0}\left(\zeta_{1}\right)$ define functions $u_{x_{1}}^{1.0} ; u_{y_{1}}^{1.0}$. In particular, when $\xi_{1}=0\left(x_{1}=0\right.$ or $\left.y_{1}= \pm \gamma\right)$

$$
\begin{gathered}
\varphi_{1}^{0}\left(\eta_{1}\right)=\frac{A}{\sqrt{\eta_{1}^{2}-l_{1}^{2}}} ; \\
u_{y_{1}}^{1.0}=0 ; \quad u_{x_{1}}^{1.0}=\frac{A}{\sqrt{\zeta_{1}^{2}-\eta_{1}^{2}}} ; \quad\left(\left|\eta_{1}\right|<l_{1}\right) ; \\
u_{y_{1}}^{1.0}=\frac{A}{\sqrt{\eta_{1}^{2}-l_{1}^{2}}} ; \quad u_{x_{1}}^{1.0}=0 ; \quad\left(\left|\eta_{1}\right|>l_{1}\right) .
\end{gathered}
$$

The normal stress $\sigma_{1}^{0}$ and the shear stress component $\tau^{1,0}$ corresponding to the function $u^{1.0}$ are found from formulas

$$
\begin{aligned}
& \sigma_{1}^{0}=B_{1}\left(R_{0} e^{\xi}\right)^{-1} u_{\xi}^{1.0}=\left(R_{0} e^{\xi}\right)^{-1} \sqrt{G B_{1}} u_{x_{1}}^{1.0} \\
& \tau^{1.0}=G u_{\eta}^{1.0}\left(R_{0} e^{\xi}\right)^{-1} u_{\xi}^{1.0}=G\left(R_{0} e^{\xi}\right)^{-1} u_{\eta_{1}}^{1.0} .
\end{aligned}
$$


The constant $A$ is determined from the equilibrium condition of the stamp and is equal to

$$
A=-P_{0}\left[(4 \gamma / \pi) R_{0}^{-1} \sqrt{G B_{1}} K\left(l_{1}\right)\right]^{-1},
$$

where $l_{1}=\sin (\pi \lambda / 2 \gamma), K\left(l_{1}\right)$ is a complete elliptic integral of the first kind.

The pressure under the stamp in the first approximation is expressed as follows

$$
\sigma_{1}^{0}=-\frac{P_{0} \pi}{4 \gamma K\left(l_{1}\right)} \frac{1}{\sqrt{l_{1}^{2}-\eta_{1}^{2}}},
$$

and the function $u_{v_{1}}^{1.0}$ under condition $\xi_{1}=0,\left|\eta_{1}\right|>l_{1}$ is found from the formula

$$
u_{y_{1}}^{1.0}=\frac{A}{\sqrt{\eta_{1}^{2}-l_{1}^{2}}},
$$

where $A$ is given by (11). The component $v^{1.0}$ of the displacement vector component $v^{0}$ in this approximation is determined from equation (3) corresponding to a given stressed state. The function $u^{1.0}$ is found from relations for $u_{x_{1}}^{1.0}, u_{y_{1}}^{1.0}$, respectively with $\left|\zeta_{1}\right|<l_{1} ;\left|\zeta_{1}\right|>l_{1}$, taking into account that $y_{1}=\eta= \pm \gamma ; u^{1.0}=$ $=0$. In particular, when $x_{1}=0(\xi=0),\left|y_{1}\right|=|\eta| \leq \lambda, u^{1.2}=c_{0}=$ $=(2 \gamma / \pi) A \ln \left(l_{1}\right)[\cos (\pi \lambda / 2 \gamma)]^{-1}$. This value determines the sag of the stamp. For $x_{1}=0$ and sufficiently close $y_{1}$ to the corner point of the stamp on the free boundary, the displacement $u^{1.0}$ can be found from the formula

$$
u^{1.0}=\frac{2 \gamma}{\pi} A \frac{\ln \left(\sin \left(\pi y_{1} / 2 \gamma\right)+\sqrt{\sin \left(\pi y_{1} / 2 \gamma\right)^{2}-l_{1}^{2}}\right)}{\cos \left(\pi y_{1} / 2 \gamma\right)} .
$$

Solution for the second type stressed state. The second component $v^{2.0}$ of the displacement vector component $v^{0}$ corresponding to the stressed state of the boundary layer type is found from the equation [2]

$$
G v_{\xi \xi}^{2.0}+B_{2} v_{\eta \eta}^{2.0}=0
$$

Note that components $v^{1.0}$ and $v^{2.0}$ have the same order of $\varepsilon=G / B_{1}$, but the derivative $v_{\xi}^{2.0}$ is greater than the derivative $v_{\xi}^{1.0}$ by two orders at $q=B_{2} / B_{1} \approx 1$. Therefore, in this approximation, boundary conditions for determining $v^{2.0}$ from equation (14) are written as follows

$$
\begin{aligned}
& v_{\xi}^{2.0}=-u_{\eta}^{1.0}(\xi=0, \lambda<|\eta|<\gamma) ; \\
& v_{\xi}^{2.0}=0(\eta= \pm \gamma) ; \\
& G v_{\xi}^{2.0}=\rho R_{0} \sigma_{1}^{0}(\xi=0,|\eta|<\lambda) .
\end{aligned}
$$

In this case, as was supposed in the statement of the problem, $\rho<1\left(\rho=\rho_{0} \varepsilon^{1 / 2}, \rho_{0} \approx 1\right)$. The component $u^{2.0}$, corresponding to a given stressed state satisfies the condition [2] $u_{\xi \xi}^{2.0}=0$.

After introducing new independent variables $x_{1}=$ $=\left(B_{2} / G\right)^{1 / 2} \xi ; y_{2}=\eta$, the boundary value problem $(14,15)$ takes the form

$$
\begin{gathered}
v_{x_{2} x_{2}}^{2.0}+v_{y_{2} y_{2}}^{2.0}=0 \\
v_{\frac{\overline{2}}{2}}^{2.0}=-\left(G / B_{2}\right)^{1 / 2} u_{y_{2}}^{1.0}\left(x_{2}=0, \lambda<\left|y_{2}\right|<\gamma\right) ; \\
v_{x_{2}}^{2.0}=0\left(y_{2}= \pm \gamma\right) ; \\
v_{x_{2}}^{2.0}=\rho R_{0}\left(G B_{2}\right)^{1 / 2} \sigma_{1}^{0}\left(x_{2}=0,\left|y_{2}\right|<\lambda\right) .
\end{gathered}
$$

The problem $(16,17)$ is the Neumann problem for the function $v^{2.0}\left(x_{2}, y_{2}\right)$, which can be solved by reflecting the halfstrip from the plane $z_{2}\left(z_{2}=y_{2}+i x_{2}\right)$ into the upper half-plane of the images $\zeta_{2}\left(\zeta_{2}=\eta_{2}+i \xi_{2}\right)$. The reflecting function has the form (6) with $\zeta_{1}$ replaced by $\zeta_{2}, z_{1}$ by $z_{2}$. In this case, points $x_{2}=0, y_{2}= \pm \lambda$ image into points $\xi_{2}=0 ; \eta_{2}=\sin (\pi \lambda / 2 \gamma)= \pm l_{1}$, and points $x_{2}=0, y_{2}= \pm \gamma-$ into points $\xi_{2}=0, \eta_{2}= \pm 1$. In addition, at $\eta= \pm \gamma\left(y_{1}=y_{2}=\eta\right) \xi_{2}=\xi_{1}=0$, and $\eta_{1}, \eta_{2}$ changes from \pm 1 to $\pm \infty$. Therefore, it follows from relations (17) with allowance for $(12,13)$ that on the real axis $\left(\xi_{2}=0\right)$ of the half-plane $\zeta_{2}$ the function $v_{x_{2}}^{2.0}$ takes the following values

$$
\begin{gathered}
v_{x_{2}}^{2.0}=\rho A \sqrt{\frac{B_{1}}{B_{1}}} \frac{1}{\sqrt{l_{1}^{2}-\eta_{2}^{2}}} ;\left(\left|\eta_{2}\right|<l_{1}\right) ; \\
v_{x_{2}}^{2.0}=-A \sqrt{\frac{G}{B_{2}}} \frac{1}{\sqrt{\eta_{2}^{2}-l_{1}^{2}}} ;\left(l_{1}<\left|\eta_{2}\right|<1\right) ; \\
v_{x_{2}}^{2.0}=0 ; \quad\left(\left|\eta_{2}\right|>1\right) .
\end{gathered}
$$

If $\psi^{0}=v^{2.0}+i Q^{2.0} ;\left(Q^{2.0}\right.$ is a harmonic function conjugate to $v^{2.0}$ ), then $\psi_{1}^{0}=i \psi_{y_{2}}^{0}=v_{x_{2}}^{2.0}+i v_{y_{2}}^{2.0}$. The function $\psi_{1}^{0}$ at any point of the upper half-plane can be defined by means of an integral of Cauchy type

$$
\psi_{1}^{0}\left(\zeta_{2}\right)=\frac{1}{\pi i} \int_{L} \frac{f(t) d t}{1-\zeta_{2}}+i k,
$$

where $L$ is the boundary of the half-plane, $\left(\xi_{2}=0\right), f(t)=$ $=v_{x_{2}}^{2.0}\left(\eta_{2}\right), k$ is an arbitrary real constant, which further will be assumed equal to zero.

From (19), taking into account (18), we obtain

$$
\begin{gathered}
\psi_{1}^{0}\left(\zeta_{2}\right)=\rho A \sqrt{\frac{B_{1}}{B_{2}}} \frac{1}{\sqrt{l_{1}^{2}-\zeta_{2}^{2}}}-\frac{A}{\pi i} \sqrt{\frac{G}{B_{2}}} \frac{1}{\sqrt{\zeta_{2}^{2}-l_{1}^{2}}} \times \\
\times\left[\ln \frac{\zeta_{2}-1}{\zeta_{2}+1}+\ln \frac{\left(\zeta_{2}+l_{1}^{2}\right)+\sqrt{\left(\zeta_{2}^{2}-l_{1}^{2}\right)\left(1-l_{1}^{2}\right)}}{\left(\zeta_{2}-l_{1}^{2}\right)+\sqrt{\left(\zeta_{2}^{2}-l_{1}^{2}\right)\left(1-l_{1}^{2}\right)}}\right] .
\end{gathered}
$$

The derivatives $v_{x_{2}}^{2.0}, v_{y_{2}}^{2.0}$ through the function $\psi_{1}^{0}\left(\zeta_{2}\right)$ are defined as $v_{x_{2}}^{2.0}=\operatorname{Re} \psi_{1}^{0}\left(\zeta_{2}\right), \quad v_{y_{2}}^{2.0}=\operatorname{Im} \psi_{1}^{0}\left(\zeta_{2}\right)$.

This completes the solution of the problem in the first approximation. The pressure under the stamp is determined by the formula (12), and the shear stress $\tau$ below it has the form $\tau^{0}=\rho \sigma_{1}^{0}$. Since $u_{\xi}^{2.0}=0$, boundary conditions for determining functions $u^{1.1}, v^{2.1}$ in the second approximation are equal to zero [2].

Correspondingly, functions $u^{2.1}, v^{1.1}$ are zero. Therefore, solutions are zero; the second approximation does not introduce corrections into the first approximation (the expansion of solutions is over integer powers of the parameter $\varepsilon$ [2]).

The influence of friction on the pressure under the stamp is taken into account only in the third approximation. In this case, there is a discrepancy in the deformation $u_{\xi}\left(\xi=0, l_{1}<\right.$ $<|\eta|<1$ ), which is removed when equation (1) for the function $u^{1.2}$ is being solved. The boundary conditions for determining $u^{1.2}$ for $\xi=0$ are $u_{\xi}^{1.2}=u_{\xi}^{1.0}-\mu v_{v}^{1.0}\left(l_{1}<|\eta|<1\right), u_{\eta}^{1.2}=0 \quad\left(|\eta|<l_{1}\right)$. At infinity, all functions are equal to zero. Since $u_{\xi}^{1.0}=0\left(|\eta|>l_{1}\right)$, then $u_{\xi}^{1.2}=\mu u^{1.0}\left(\xi=0, l_{1}<|\eta|<1\right)$.

Here, $\mu=\vartheta_{1} B_{1} / G=\vartheta_{2} B_{1} / G$ and we take into account the relationship between $v_{\eta}^{1.0}$ and $u^{1.0}$, which is conditioned by equality (3). Thus, the discrepancy for normal stresses $\sigma_{1}$ for $\xi=0, l_{1}<|\eta|<1$ is caused only by the Poisson ratio. The solution of the formulated problem repeats what was stated 


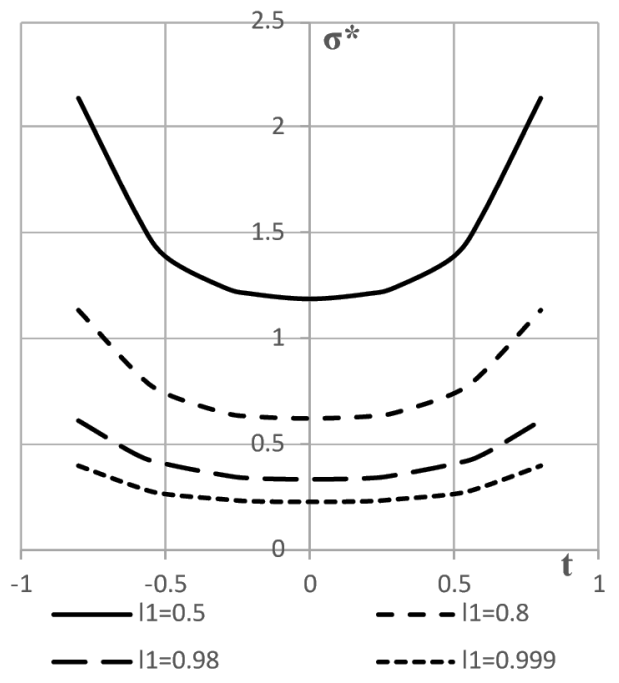

Fig. The dependence of the distribution of normal stress under the stamp on $l_{1}$

above, but under the boundary conditions which are indicated above.

Conclusions. The asymptotic method, which was proposed for solving nonlinear partial differential equations, is important from theoretical and practical points of view. It is universal and can be used to analyze various problems of mathematical physics.

The described approach can be applied to solving such a problem class in which taking into account the real material properties leads to significant mathematical difficulties in the process of solving.

During the solution, a relationship was established between the dimensions of the coupling area, the interaction region, the angle of the sector solution and the friction coefficient.

It should be noted that if the friction coefficient $\rho$ tends to zero, the friction area disappears. Conversely, if it increases, the area of adhesion increases as well. The magnitude of the stresses also depends on the size of the stamp, as shown in Figure. Here $\sigma_{1}=\frac{1}{l_{1} K\left(l_{1}\right)} \frac{1}{\sqrt{1-t^{2}}}$, where $\left(-1<l_{1}<1,-1<t<1\right)$, $t=\frac{\eta_{1}}{l_{1}}=\frac{\sin \left(\pi y_{1} / 2 \gamma\right)}{\sin (\pi \lambda / 2 \gamma)}$ at $\left(x_{1}=0,-\lambda<y_{1}<\lambda\right)$.

The obtained solutions can be used in modeling fastenings curved (semi-cylindrical or circular) workings, wells, pipelines. The most valuable in this matter is the friction consideration in the reinforcing element and the matrix (soil) interaction.

\section{References.}

1. Kagadiy, T.S., \& Shporta, A.H. (2015). The asymptotic method in problems of the linear and nonlinear elasticity theory. Naukovyi Visnyk Natsionalnoho Hirnychoho Universytetu, 3, 76-81.

2. Kaminsky, A. O., \& Selivanov, M.F. (2017). Slow crack growth with contact area. Reports of the National Academy of Sciences of Ukraine, 1, 38-43. DOI:10.15407/dopovidi2017.01.038.

3. Kriven, I., \& Yavorskaya, M. (2010). Development of plastic strips in the vicinity of the vertices of the two arcs of symmetric cut out under antiplastic deformation. Phys.-Math. modeling and inform. Technology, (11), 91-96.

4. Dziubik, A. R., Nykolyshyn, T. M., \& Porokhovskyi, Yu. V. (2016). Influence of residual stresses on the boundary equilibrium of a pipeline with an internal split of arbitrary configuration. Physical-chemical mechanics of materials, 52(1), 83-90.
5. Bomba, A. Ya., Prysiazhniuk, I. M., \& Prysiazhniuk, O. V. (2013). Asymptotic method for solving a class of model singularly perturbed problems of the mass transfer process in heterogeneous media. Reports of the National Academy of Sciences of Ukraine, 3, 28-34.

6. Kliuchnyk, I. (2014). Integration of a system of differential equations with a small parameter in the part of derivatives / I. Glyuchnyk. Bulletin of the Donetsk National University. Ser A: Natural sciences, (2), 21-25.

7. Staroselsky, A., Acharya, R., \& Cassenti, B. (2019). Phase field modeling of fracture and crack growth. Engineering Fracture Mechanics, 205, 268-284. DOI:10.1016/j.engfracmech.2018.11.007.

8. Kolosov, D., Dolgov, O., \& Kolosov, A. (2014). Analytical determination of stress-strain state of rope caused by the transmission of the drive drum traction. In V. Bondarenko, I. Kovalevs'ka, K. Ganushevych (Eds.), Progressive Technologies of Coal, Coalbed Methane, and Ores Mining ( $1^{\text {st }}$ ed., pp. 499504). CRC Press.

9. Kelby, B., \& Baka, Z. (2019). Annual crack in an elastic half-space. International Journal of Engineering Science, (134), 117-147. DOI:10.1016/j.ijengsci.2018.10.007.

10. Ostrik, V. I. (2008). Injection of semi-non-stamp in elastic band in the presence of friction and adhesion. Math. methods and physical fur. Fields, 51(1), 138-149.

\section{Математичне моделювання при розрахунку підкріплюючих елементів}

\section{Т. С. Кагадій, А. Г. Шпорта}

Національний технічний університет „Дніпровська політехніка“, м. Дніпро, Україна, e-mail: kagadiy@i.ua; shportaanna@ukr.net

Мета. Визначення законів розподілу напружень, що виникають під час взаємодії жорсткого штампу та пружної пластини з циліндричною анізотропією. Моделювання задач контактних взаємодій із ціллю визначення процесів зносу, міцності, руйнування й довговічності конструкцій і споруд. Розробка аналітичних методів розрахунку взаємодій конструкцій під час контакту, з урахуванням різноманітних властивостей матеріалу.

Методика. Складена математична модель просторової задачі, що розглядає контакт жорсткого штампу та кругового сектора, який має властивості матеріалу, відповідні до циліндричної анізотропії. Для проведення аналітичного дослідження моделі запропоновано асимптотичний метод, який дозволяє розчленити напруженодеформований стан кругового сектора, що за умовою $є$ нескінченним, на дві складові. У такому разі вдається перейти від розв'язання задачі, що відноситься до розділу теорії пружності, до послідовного розв'язання задач теорії потенціалу.

Результати. У цій роботі досліджена конкретна задача про взаємодію. Для знаходження розв'язку тут застосований асимптотичний метод. Під час розв'язання поставленої задачі враховане тертя, що виникає у процесі взаємодії між жорстким штампом і пластиною із пружного матеріалу. Розглянута задача $є$ новою й достатньо складною. Вона викликає значні труднощі при розгляді. Тому отриманий аналітичний розв'язок є корисним результатом для подальшого аналізу або чисельних розрахунків. Знайдені значення тиску під штампом, ураховано вплив тертя.

Наукова новизна. Запропонований раніше метод узагальнений на випадок циліндричної анізотропії матеріалу. Отримано аналітичний розв'язок нової складної просторової задачі про взаємодію.

Практична значимість. Асимптотичний метод, що запропонований у даній роботі, дозволяє перейти від 
розв'язання складних мішаних механічних задач до послідовного розв'язання крайових задач, які мають відношення до теорії потенціалу. Слід урахувати, що теорія потенціалу є найбільш висвітленим розділом у математичній фізиці. Розв'язки, отримані завдяки запропонованому методу, дають змогу аналізувати напружено-деформований стан, що виникає у ході розв'язання поставленої задачі. Розглядається наступна задача: у вільну грань нескінченного кругового сектора, що є пружним, ортотропним, а також матеріал якого володіє властивостями циліндричної анізотропії, вдавлюється жорсткий штамп. Кромки кругового сектора закріплені. Застосування отриманих результатів можливе під час розрахунку й конструюванні різноманітного роду кріплень.

Ключові слова: штамп, взаємодія, анізотропія, асимптотичний метод, просторові задачі, тертя, сектор

\section{Математическое моделирование при расчете подкрепляющих элементов}

\section{T. С. Кагадий, А. Г. Шпорта}

Национальный технический университет „Днепровская политехника“", г. Днепр, Украина, e-mail: kagadiy@i.ua; shportaanna@ukr.net

Цель. Определение законов распределения возникающих напряжений при взаимодействии жесткого штампа и упругой пластины с цилиндрической анизотропией. Моделирование задач контактных взаимодействий с целью определения процессов износа, прочности, разрушения и долговечности конструкций и сооружений. Разработка аналитических методов расчета взаимодействий конструкций во время контакта, с учетом различных свойств материала.

Методика. Составлена математическая модель пространственной задачи, которая рассматривает контакт жесткого штампа и кругового сектора, обладающего свойствами материала, соответствующими цилиндрической анизотропии. Для проведения аналитического исследования модели предложен асимптотический метод, позволяющий расчленить напряженно-деформированное состояние кругового сектора, который по условию бесконечен, на две составляющие. При этом удается перейти от решения задачи, относящейся к теории упругости, к последовательному решению задач теории потенциала.

Результаты. В данной работе исследована конкретная задача о взаимодействии. Для нахождения решения здесь применен асимптотический метод. В ходе решения поставленной задачи учтено трение, возникающее в процессе взаимодействия между жестким штампом и пластиной из упругого материала. Рассмотренная задача является новой и достаточно сложной. Она вызывает значительные трудности при рассмотрении. Поэтому полученное аналитическое решение является полезным результатом для дальнейшего анализа или численных расчетов. Найдены значения давления под штампом, учтено влияние трения.

Научная новизна. Предложенный ранее метод обобщен на случай цилиндрической анизотропии материала. Получено аналитическое решение новой сложной пространственной задачи о взаимодействии.

Практическая значимость. Асимптотический метод, который предложен в данной работе, позволяет перейти от решения сложных смешанных механических задач к последовательному решению краевых задач, относящихся к теории потенциала. Следует учесть, что теория потенциала является наиболее освещенным разделом в математической физике. Решения, полученные благодаря предложенному методу, дают возможность анализировать напряженно-деформированное состояние, возникающее в ходе решения поставленной задачи. Рассматривается следующая задача: в свободную грань бесконечного кругового сектора, который является упругим, ортотропным, а также материал которого обладает свойствами цилиндрической анизотропии, вдавливается жесткий штамп. Кромки кругового сектора закреплены. Применение полученных результатов возможно при расчете и конструировании различного рода креплений.

Ключевые слова: штамп, взаимодействие, анизотропия, асимптотический метод, пространственные задачи, трение, сектор

Рекомендовано до публікації докт. техн. наук О. О. Сдвижковою. Дата надходження рукопису 22.11.18. 